\title{
Martin Jay: An Encounter Between Philosophy AND HISTORY
}

\author{
Martin Jay: Un encuentro entre la filosofía y la historia ${ }^{1}$
}

\author{
MARTIN JAY \\ University of California, Berkeley
}

\begin{abstract}
The interview took place in Santiago, Chile in November 2015 and was conducted by Gonzalo Bustamante, professor of political philosophy at Universidad Adolfo Ibáñez. Martin Jay in the course of this interview addresses the links between Critical Theory, Cambridge School, and Conceptual History, giving special attention to an "event" as a limited category, critical rationality and the contextual genealogies of the different branches of historical studies mentioned before. Jay concludes that one of the possible limitations of the "in context' work of authors such as Quentin Skinner and the socalled Cambridge School is given by the impossibility to reduce the perlocutionary effect of events to the illocutionary intentions of the authors. In line with Claude Romano, in the interpretation of Jay, an 'event' always has an "an-archic" condition that makes its limitation to previous networks of meaning impossible.
\end{abstract}

Key words: Jay, Skinner, event, Begriffsgeschichte, Critical Theory.

\begin{abstract}
RESUMEN
La entrevista tuvo lugar en Santiago, Chile en noviembre del año 2015 y fue realizada por Gonzalo Bustamante, profesor de filosofía política de la Universidad Adolfo Ibáñez. En ella, Martin Jay aborda los entrecruzamientos entre Teoría Crítica, el giro lingüístico de la llamada Escuela de Cambridge e Historia Conceptual, prestando especial atención a los vínculos entre 'acontecimiento' (event) como categoría límite, racionalidad crítica y la genealogía contextual de las corrientes antes mencionadas. Jay concluye que uno de los posibles límites de la propuesta 'in context' de autores como Quentin Skinner y la Escuela de Cambridge, estaría dado por la imposibilidad de reducir los efectos perlocutivos de un 'acontecimiento' a las intenciones ilocutivas de sus autores. En línea con Claude Romano, en la interpretación de Jay, todo 'acontecimiento' tiene siempre una condición "anárquica" que imposibilita su limitación a redes de sentido previas.
\end{abstract}

Palabras clave: Jay, Skinner, acontecimiento, Begriffsgeschichte, Teoría Crítica. 


\section{INTRODUCTION}

Martin Jay's work, on both critical theory and historiography, is some of the most outstanding in recent decades. The range of his work, and resultant difficulty classifying it, is reflected in The Modernist Imagination: Intellectual History and Critical Theory Essays in Honor of Martin Jay, a collection edited by Warren Breckman, Peter E. Gordon, A. Dirk Moses, Samuel Moyn, and Elliot Neaman.

Over the course of his work, Jay has developed a perspective critically addressing the ideas of Quentin Skinner and the so-called Cambridge School. In this way, he indicates that one of the possible limitations of the linguistic context analysis à la Skinner is given by what Claude Romano says in relation to "event". Jay agrees with Romano in the sense that in an "event" the perlocutionary effect of texts that qualify as cultural events are irreducible to the illocutionary intent of their authors. At the same time, Jay concurs with Romano that an "event" always has an an-archic condition that makes its limitation to contextual networks of meaning impossible, in the form of arches $^{2}$ that produce or predetermine their occurrence. ${ }^{3}$

This interview addresses precisely these links between Critical Theory, the Cambridge School, Conceptual History, and the event as a "limited category". Similarly, it addresses the extent to which the idea of a critical rationality supports these categories and the corresponding linguistic and rhetorical turn.

Gonzalo Bustamante: You have addressed a wide range of issues in your work which are relevant in several fields. This makes it difficult to choose a starting point. Since our conversation will be about "History and Critical Theory", let me start with a very simple question. In the past, historians like Collingwood (historian and philosopher) have rescued the value of philosophy for history. In recent decades, we have seen the explicit use of philosophical categories to account for the necessary contextualization that history requires by authors such as Quentin Skinner, JGA Pocock and those who are akin in terms of their methodologies. The same can be said about Hayden White. If one changes one's way of thinking, in your opinion, how much "history" (and what aspects of it) does "political philosophy" require in order to be "critical" without becoming disfigured theoretically?

Martin Jay: Any philosophical inquiry that descends into the world, leaving behind metaphysical or transcendental questions about matters that claim eternal and universal status, necessarily has to reckon with historical change and variation. A philosophy

Regarding the concept 'an-arché' in the tradition of the critical theory, see: Schürmann, 1987.

Romano (2009) first states, "an 'intended meaning' and a language must 'precede' an act of speech, which would be impossible without them. However, speech, like an event, is irreducible to its own 'conditions' and annuls them in arising" (...) But Romano then develops his argument in a more radical direction. All events might seem to be comprehensible in terms of their enabling contexts, he indicates, "were it not for events that radically upend their contexts and, far from being submitted to a horizon of prior meanings, are themselves the origin of meaning for any interpretation, in that they can be understood less from the world that precedes them than from the posterity to which they give rise" [Romano, quoted in Jay, (2011), p. 564]. 
of politics can only have arisen when a distinct realm of human endeavor that can be called political emerged out of a relatively undifferentiated totality of human practices, creating enough autonomy that theorists can reflect on its special characteristics. Whether we imagine this happening with the rise of the polis, the monarchy, the state or some other institution and set of practices, it has to be understood as having happened in history, and therefore inevitably carrying the traces of its origins. Politics, however we may define it, is a human contrivance invented by a society advanced enough to need procedures and institutions to cope with the imbalances of power, clash of values and conflicts of interest that arise alongside of increased social complexity. It is always already embedded in the real world out of which it comes.

But it is no less the case that once political practices emerge and gain the inertial force of tradition, they paradoxically have the capacity to transcend their origins and serve as models for later appropriation and development. In so doing, they gain enough autonomy to justify more abstract attempts to locate their essential characteristics that endure in different settings. Thus, it is possible to do a comparative study of kingship in many different cultures and over many different centuries, because we can discern certain similarities in the ways monarchy functions everywhere. The concept of the monarchy thus gains a certain distance from its instantiations, which are imperfect exemplars of it. It is also possible to infuse such concepts with normative force, as has happened with such political terms as liberal, democratic or socialist. That is, we can have an idealized version of a form of political organization that allows us to measure the deficiencies of their current embodiments. We can differentiate, for example, between "actually existing socialism" and the model of realized socialism that is desired in the future.

It is, we might say, in the dialectic between embeddedness and historical specificity, on the one hand, and the normative force of certain concepts on the other, that critique becomes possible. Or, as the left Hegelians would have put it, when we say the real is rational, what we mean is that what exists will not become really "real" until it has also become "rational". But at the same time, we have to engage in a learning process that allows us to critically analyze the idealized concept itself, based on the experiences we have had in trying to realize it. Our current state of affairs may not be a fulfillment of the normative concept we employ to criticize it, but it may well cause us to modify and -one hopes- improve the concept itself. To remain with the example of the Left Hegelians, we have to question the implied meaning of rationality itself, which is by no means a fixed and univocal concept. In my new book, Reason after its Eclipse: On Late Critical Theory (2016) I try to explore some of its many meanings and uses since the Ancient Greeks first posited the idea of Logos.

Gonzalo Bustamante: Talking about Quentin Skinner, he wrote a harsh review of Habermas's thought titled "Habermas's Reformation" (NYR October 7, 1982), to which he received an equally harsh response by Thomas McCarthy, "Defending Habermas" (NYR January 20, 1983). This debate and the fact that you know both traditions (that of Cambridge and that of Frankfurt) makes me ask the following double question: To what extent does the contextualism of the Cambridge School allow for the possibility 
of a critical theory, be it that of Habermas or even of Honneth? Along the same lines, you have suggested that the category "event" represents a limit to the applicability of the same contextualism. Does that category (event) mark the need for a critical theory versus contextualism?

Martin Jay: Although at first glance it may seem that an excessive emphasis on reducing all ideas to the contexts of their generation and reception would dull the edge of critique, it would be only fair to recall that Skinner himself has demonstrated a strong interest in the notion of liberty inherited from the Roman idea of the homo liber as contrasted with the servus, who is dependent on the will of another and unable to act in his own right. He traces the fortunes of what he calls the neo-Roman idea of liberty through later figures like Machiavelli and Shakespeare and is interested in its threatened survival in our own day. As he told a recent interviewer, "I think that we have closed ourselves off from understanding a lot of our history by failing to see that, until relatively recently, the concept of liberty was generally understood in a way that we now find unfamiliar and even hard to grasp. We tend to think of freedom essentially as a predicate of actions. But the earlier tradition took freedom essentially to be the name of a status, that of a free person by contrast with a slave" ${ }^{4}$ We may quarrel with his negative definition of freedom and prefer the more positive one he challenges in this citation, but we can't deny that he is drawing on a contextualist approach for critical purposes.

Having said that, I would nonetheless agree that a contextualism that seeks to remain entirely in the universe of discourse that it hopes to recreate historically will fail to understand the inevitable negotiation that occurs between our present concerns, our fears as well as hopes, and those of the past figures whose lives and ideas we want to protect from a straightforward imposition of later values and prejudices. That is, the living can't entirely bracket who we are in our intercourse with the dead, even as we rightfully attempt to expand our horizons by that very intercourse. The questions we ask of history are always our questions, not theirs, even if we strive to let their questions emerge through the filter of our own prejudices. In its insistence on rejecting any hint of anachronism, one-dimensional contextualism struggles in vain to bracket the intervening years -what Hans-Georg Gadamer called the effective-history- that necessarily colors our understanding of the past. Although the result may not be a harmonious fusion of horizons, it is always something more than an imaginative re-enactment of what past actors may have experienced or thought, circumscribed by their own hermeneutic context.

As for the implications of the "event", a term with many different meanings and lots of emotional valence, I would say that to the extent that it alerts us to the possibilities of disruption and innovation, it is a useful counterweight to a suffocating contextualism that assumes everything flows from a prior situation or tradition (or at best the conjuncture of different causal chains). But there is nothing inherently critical in the ways in which such a disruption brings about a radical change or something new in the world. 9/11 was by most measures an "event", which changed a great deal, but I can only think 
of it as a disaster for both its literal victims and the world at large. What constitutes progressive critique is never easy to say, but it certainly can't be equated with events as such. As we know, bolts of lightning, to recall Nietzsche's metaphor of an event, can cause destruction as well as illumination.

Gonzalo Bustamante: The category "event" has a long tradition: In "History" its categorization by Carlo Diano ${ }^{5}$ (Forma ed Evento) for analyzing antiquity is essential. Sheldon Wolin (recently deceased) recovers its importance for contemporary political theory. Diano shows that there will be times when the emphasis will be on the "form" and others when it will be on the "event". In your opinion, is the regained value of "event" in current political philosophy a sign that we are in an era dominated by the "event" more than the "form?" If the answer is yes, to what extent does this predominance of "event" not imply the need to distance oneself from normative theories about the "rule of law" such as that of Rawls? I ask this because the "rule of law" (and procedural normative value) by definition would be a "form", not an "event". By contrast, decisionism (the one that Seneca recommended in De Clementia ${ }^{6}$ or the one that today has been revived by Schmitt) favors the action of an event itself.

Martin Jay: Whether we call it form and event, intelligibility and contingency, structure and agency, or a dozen other comparable dichotomies, the dialectic of continuity and discontinuity is a perennial challenge to our understanding of historical change. In the arena of rational-legal authority we call the "rule of law", it plays out in several ways. First, in the making of law, there is, as Schmitt observed, an often forgotten moment of initial legitimation through arbitrary fiat that then gives subsequent law-making the authority to create the procedures and protocols that seem to function autonomously and "above" the individuals whose actions they judge. A foundational event, in other words, precedes a form, which then becomes the framework allowing later rules to be legislated under which subsequent acts can be judged. Or at least such acts can be construed as "under the law" in normal situations of binding legality and not during what Schmitt would have called a "state of emergency" or "exception", in which the forms have lost their legitimacy, necessitating a new act -or "event"- of legitimation ex nihilo. Whether these suspensions of the rule of law are as frequent and the arbitrary decisions to found a new order happen as often as Schmitt assumed is, however, questionable. We are rarely in revolutionary or anarchic situations in which an entire legal order is deemed illegitimate or time-honored forms are utterly discredited, even if there is always the possibility that such a radically disruptive event might occur that it then necessitates a new legitimating fiat. The rule of law, after all, does not merely mean the conservative preservation of existing legal forms, but also the procedures for their legitimate transformation, for example through democratically produced legislation.

Diano (1967).

In this text, Seneca defends mercy as a power of the monarch, one based not on the weakness or defect of an 'old cry baby without character' but on wisdom and determination. In a way, it is possible to see this work as a precursor to the decisiveness of Hobbes and Schmitt. See: Seneca (1995). Regarding the importance of Seneca's thinking during the Renaissance, see: Stacey (2007). 
A true state of emergency happens only when those formal procedures are themselves called into question and lose their ability to perpetuate the legitimacy of the order they embody through legally sanctioned change. Once laws are in place, moreover, the absolute power of a sovereign will itself relativized by procedures that themselves need to be followed before a state of emergency can be declared. Sovereign power is, after all, more than just brute force; it involves the recognition of authority.

In addition to the law-making moment in the rule of law, there is also a law-enforcing one. That is, the application of general laws to specific cases, the fairness of procedures that assure that no one is "above the law", means that enduring forms exist under which individual acts can be judged. Here too, there is a possibility for the return of a formsuspending event in the guise of an act of clemency or mercy that allows the executive in a state with a division of powers to contravene the judicial decision to apply the law in a particular case. Like a miracle that suspends the laws of nature performed by a God with the power to intervene in His creation, clemency is a decision by someone who is granted the right to be "above the law". Or course, the right to make such a decision legitimately is very circumscribed and rarely exercised, which means once again that in the dialectic of form and event, the rule of law is overwhelmingly on the side of the former. A singular suspension of law enforcement does not mean, in fact, that the law is itself overturned or even weakened. The rare exercise of clemency is an exception that, unlike in the case of law-making, does not call into question the legitimacy of the legal system as a whole that permits it. In fact, we might say that it is evidence that the system has a place for flexibility and self-correction that helps it to survive. Clemency is the moment of grace that softens the stern rigor of justice.

Gonzalo Bustamante: In social sciences (in quite a few areas) we have seen a revival (almost a trend) of the rhetorical turn. Undoubtedly, the contribution of American literary criticism to the study of rhetoric and deconstructionism is very significant. I am referring, to name only two examples, to the works of Wayne C. Booth and Kenneth Burke. $^{7}$ To what extent can this rhetorical turn be seen as a new form of critical theory that goes beyond the Frankfurt School and surpasses it historically within the social sciences? Incidentally, and as a side note to "American literary criticism", do you believe that people like Burke are the real parents of what we now know as deconstructionism and not, for example, Derrida?

Martin Jay: I would agree that rhetoric has regained some of the respect that it lost when the model of clarity was scientific or even mathematical language, purged as much as possible of its polysemic indeterminancy. Booth and Burke were once crying in the wilderness, and although I'm not sure either is really all that influential today, at

7 Booth (1961, 1974, and 2004) are pivotal here. Works of Burke worth highlighting here include Burke (1937, 1941, 1950, and 1966). On Burke, also see http://www.kbjournal.org/content/works-kenneth-burke (last consulted, february $17^{\text {th }}$ ). The prominent historian and economist Deirdre McCloskey defends the contribution of American literary criticism to the social sciences, including economics, and applies rhetorical analysis to criticize the methodology of neoclassical economics. See: Burke (1998). 
least we recognize the importance of the themes they explored. As Hans Blumenberg8 once put it, rhetoric is what might be called our principle of "insufficient reason", which somehow allows us to muddle through despite the inadequacies of a strong or emphatic concept of rationality. Whether or not it provides the point d'appui for a meaningful critique of social and political injustice is another thing. I think we can learn a lot from rhetorical analysis and become more self-conscious about the ways language works to advance and to thwart our goals, but I don't think it suffices as a basis for critique. There needs to be as well the intersubjective exercise of rational judgment, allowing us to cut through the potential for obfuscation in rhetoric alone.

Gonzalo Bustamante: Shimon Peres 9 once said that the characteristic of "being Jewish" was "to be rebellious". In a way, one could interpret the birth of the Frankfurt School (not as something mono-causal, that is) from this point of view. Does Judaism have its own "political theology" that reflects this rebellion? If so, what would be the characteristic of this Jewish "political theology"10 that possibly cannot be found in any "Christian" one?

Martin Jay: We are entering very sensitive and potentially dangerous territory here. Despite Peres's remark, I have grave doubts that one can locate a single characteristic that defines Jewish identity, which is as varied as that of any other group. It would be easy, after all, to cite many examples of Jews who were deeply traditional and threatened by rebelliousness of any kind. As for the complicated and vexed relationship between the Jewish backgrounds -some more substantial than others- of most members of the Frankfurt School, there is an excellent new book by the American historian Jack Jacobs called The Frankfurt School, Jewish Lives and Anti-Semitism, published by Cambridge University Press, ${ }^{11}$ that does a nice job of exploring its implications. I am part of a review symposium that will be published soon by The German Quarterly. If your readers want some illumination on this subject, the book and our responses would be the first place to go.

When I say the territory is dangerous, it is because for many years, anti-Semitic enemies of the Frankfurt School attacked it as a Jewish plot, a version of cultural Marxism that continued the nefarious work of other Jewish Marxists like Luxemburg, Trotsky, Lukács, and, of course, Marx himself. So one must be very careful to avoid simplistic connections between any idea of a "Jewish theology" and Critical Theory.

Gonzalo Bustamante: Let's turn back to the Cambridge School and Critical Theory. With the work of the first, especially that by Skinner, republicanism is revived significantly in political theory. In a way, if one accepts that there was a reformulation of radical Hebrew republicanism by authors like Cohen and Rosenzweig, which could have affected authors like Benjamin, one can possibly see in both movements (with all the nuances and differences) a foreshadowing of a "neo-Machiavellian republicanism"

$8 \quad$ See Blumenberg (1987) and Bödeker (2002).

9 Peres is one of the most prominent figures in the history of Israel. Among his many positions, he has twice served as Prime Minister of Israel (1984-1986 y 1995-1996), and was President of the State of Israel 2007-2014. For an approach to political theology and Judaism, see: Rashkover and Kavka (2013).

Jacobs (2014). 
(Cambridge School) and in the other the "contemporizing (update) of a radical Hebrew republicanism"12 (Critical Theory). Is it possible to find a meeting point between the two movements on this "Republican horizon" that goes beyond the methodological debate?

Martin Jay: To be honest, this is the first time I have heard Critical Theory called a variant of Hebrew republicanism, which seems to me a very unlikely lineage. The republican tradition emphasized the relative autonomy of the political, which does not seem to me one of the Frankfurt School's premises. They were interested in the ways in which culture, politics, the economy, technology, etc., were all complexly intertwined. Although there was a problematic way in which this occurred -perhaps best expressed in Marcuse's idea of a "one-dimensional society"- there was also a utopian version, in which political institutions, such as the state, would not be fully distinct from the other dimensions of the totality. As for the idea of a "radical Hebrew" coloration to the republicanism, my response to your earlier questions suggests why I would hesitate before describing critical theory as inherently Jewish.

Gonzalo Bustamante: One last question. Begriffsgeschichte ${ }^{13}$ can be reconstructed (as many have done) from a German cultural context that starts with the "proto-Nazi" Volksgeschichte ${ }^{14}$ and openly undergoes a "Nazi" period (think Conze and Brunner) to one that rethinks these influences (Brunner, Conze, together with Schmitt, amongst others) to shape a Begriffsgeschichte as expressed by Koselleck. The same way one can detect a "rebellious Jewish spirit" in Critical Theory, one might (perhaps) also be able to spot a "German reactionary" one in Begriffsgeschichte. A difference that is not minor is that the "Jewish spirit" is in its essence cosmopolitan. Does Begriffsgeschichte need to "degermanize" in order to acquire greater universality, or can one sufficiently separate "the conceptual history of Begriffsgeschichte" from the "theory of Begriffsgeschichte" and thus forget about "degermanizing"?

Martin Jay: Although I've always been troubled by Koselleck's early debts to Schmitt, which are most evident in Kritik und Krise, and am aware of the dubious past of Brunner and Conze during the Nazi period, I don't find powerful residues of political reaction in the program of Begriffsgeschichte as a tool of intellectual history. One might, in fact, argue that Koselleck's critique of the dangerous "ideologization" of thought during the "saddle time" could be turned against the early fascist sympathies of the founders of conceptual history themselves. Koselleck's exposure of the specific historical origins of the concept of one unified History, a single narrative of humankind as a whole, can, moreover, be understood to suggest a pluralism that seems more liberal than conservative in implication. Although the German origins of the tradition shouldn't be forgotten, the

12 For one of the most outstanding works on "Hebrew republicanism", see Nelson (2011).

13 Here we refer to Begriffsgeschichte (Conceptual History) in relation to the work of Werner Conze, Otto Brunner and Reinhart Koselleck as a specific a genre developed since mid XX century in the Federal Republic of Germany. For a wider view on Conceptual History, see the classical work of Richter: 1995.

14 Volksgeschichte (the history of the German folk or people) was a strongly nationalistic and ideologized trend within the German Social History. It was influential in the birth of Conceptual History (Begriffsgeschichte). See: Van Horn Melton (1994). 
internationalization of conceptual history is striking, as was made clear to me when I attended a meeting of their professional association a few years ago in Buenos Aires. Israeli scholars like Sinai Rusinek ${ }^{15}$ are prominent figures in the current community of scholars working in this tradition. I was also struck by how prominent conceptual history is in Scandinavia on a trip a few years ago to Finland. ${ }^{16}$ There is, to be sure, always a chance that isolating concepts or ideas as the object of historical inquiry can signal an implicitly idealist philosophy, but at least initially, conceptual history was understood to be a handmaiden of social history, helping us to connect ideas and movements in society.

\section{REFERENCES}

Blumenberg, Hans. 1987. "An Anthropological Approach to the Contemporary Significance of Rhetoric". En After Philosophy: End or Transformation?, editado por Baynes, Kenneth, Bohman, James y McCarthy, Thomas. Cambridge: MIT Press, 423-458.

Bödeker, Hans Erich. 2002. Begriffsgeschichte, Diskursgeschichte, Metapherngeschichte. Göttingen: Wallstein Verlag.

Booth, Wayne. 1961. Rhetoric of Fiction. Chicago: The University of Chicago Press. 1974. Modern Dogma and the Rhetoric of Assent. Chicago: The University of Chicago Press. . 2004. Rhetoric of Rhetoric: The Quest for Effective Communication. Walden, Mass.: Blackwell.

Breckman, Warren, Gordon, Peter E., Moses, Dirk A., Moyn, Samuel and Elliot Neaman (ed.). 2009. The Modernist Imagination: Intellectual History and Critical Theory Essays in Honor of Martin Jay. New York: Berghahn Books.

Burke, Kenneth. 1937. Attitudes Toward History. 2 Vols. New York: New Republic. 1941. The Philosophy of Literary Form: Studies in Symbolic Action. Baton Rouge: Louisiana State

University Press. 1950. A Rhetoric of Motives. New York: Prentice-Hall. 1966. Language as Symbolic Action: Essays on Life, Literature, and Method. Berkeley: University of

California Press. 1998. The Rhetoric of Economics. 2nd Ed. Madison: University of Wisconsin Press.

Cohen, Hermann. 1924. Jüdische Schriften, editado por Strauss, B. Berlin: Schwetschke. Partially.

Derrida, Jacques. 1967. De la grammatologie. Paris: Minuit.

Diano, Carlo. 1967. Forma ed Evento. Venice: Neri Pozza.

Gadamer, Hans-Georg. 2004. Truth and Method. Bloomsbury Academic.

Jacobs, Jack. 2014. The Frankfurt School, Jewish Lives, and Antisemitism. Cambridge: Cambridge University Press. Jay, Martin. 2011. "Historical Explanation and the Event: Reflections on the Limits of Contextualization". New Literary History 42: 557-571.

2016. Reason after its eclipse. On late Critical Theory. University of Wisconsin Press.

Jospe, Eva (ed.) 1971. Reason and Hope: Selections from the Jewish Writings of Hermann Cohen, New York:

Norton and Norton.

Koselleck, Reinhart. 1973. Kritik und Krise. Suhrkamp Verlag.

15 Sinai Rusinek's main interests are the history of concepts and digital humanities. She is editor in chief of the journal Contributions to the History of Concepts.

16 From the prominent work of Kari Palonen, in Finland, it has developed an innovative research project on Conceptual History. Some of the works of Palonen are: The Struggle with Time. A Conceptual History of 'Politics' as an Activity (Münster: LIT Verlag, 2006); Die Entzauberung der Begriffe. Das Umschreiben der politischen Begriffe bei Quentin Skinner und Reinhart Koselleck (Münster: Lit Verlag, 2004) and Quentin Skinner. History, Politics, Rhetoric (Cambridge: Polity, 2003). 
Mueller, Jan Werner. 2014. "On Conceptual History". En Rethinking Modern Intellectual History, editado por McMahon, Darrin M. y Moyne, Samuel. Oxford: Oxford University Press, 74-93.

Nelson, Eric. 2011. The Hebrew Republic: Jewish Sources and the Transformation of European Political Thought. Cambridge: Harvard University Press.

Van Horn Melton, James. 1994. "From Folk History to Structural History: Otto Brunner and the RadicalConservative Roots of German Social History". En Paths of continuity: German Historical Scholarship, 1933-1960, editado por Van Horn Melton, James and Lehmann, Hartmut. Cambridge: Cambridge, University Press, 263-292.

Palonen, Kari. 2003. Quentin Skinner. History, Politics, Rhetoric. Cambridge: Cambridge Polity. 2004. Die Entzauberung der Begriffe. Das Umschreiben der politischen Begriffe bei Quentin Skinner und Reinhart Koselleck. Münster: Lit Verlag.

2006. The Struggle with Time. A Conceptual History of 'Politics' as an Activity. Münster: LIT Verlag.

Rashkover, Randi and Kavka, Martin. 2013. Judaism, Liberalism, and Political Theology. Bloomington: Indiana University Press.

Richter, Melvin. 1995. The History of Political and Social Concepts. New York: Oxford University Press.

Romano, Claude. 2009. Event and World. Fordham University Press.

Rosenzweig, Franz. 1988. Der Stern der Erlösung. Frankfurt am Main: Suhrkamp.

Seneca. 1995. "On Mercy". En Seneca: Moral and Political Essays, editado por J.F. Procopé. Cambridge: Cambridge University Press.

Schürmann, Reiner. 1987. Heidegger on Being and Acting: From Principles to Anarchy. Bloomington: Indiana University Press.

Skinner, Quentin. 1969. "Meaning and Understanding in the History of Ideas". History and Theory 8 (1): 3-53. .1974. "Some Problems in the Analysis of Political Thought and Action". Political Theory 2 (3): 277-303. 2002. Visions of Politics: Regarding Method, Vol. 1. Cambridge: Cambridge University Press.

Skinner Quentin and Marshall, Richard. 2013. "Liberty before Liberalism \& all That”. 3: AM Magazine (26 July). [En línea]. http://www.3ammagazine.com/3am/liberty-before-liberalism-all-that/.

Stacey, Peter. 2007. Roman Monarchy and the Renaissance Prince. Cambridge: Cambridge University Press. Wolin, Sheldon. Politics and Vision: Continuity and Innovation in Western Political Thought. Princeton: Princeton University Press.

Martin Jay is Ehrman Professor at the University of California, Berkeley. Jay's works include: Songs of Experience: Modern European and American Variations on a Universal Theme (Berkeley: University of California Press, 2005); The Dialectical Imagination: A History of the Frankfurt School and the Institute of Social Research, 1923-50 (Boston: Little, Brown and Co., 1973); Marxism and Totality: The Adventures of a Concept from Lukács to Habermas (Berkeley: University of California Press, 1984); Adorno (Cambridge, Mass.: Harvard University Press, 1984); Permanent Exiles: Essays on the Intellectual Migration from Germany to America (New York: Columbia University Press, 1985); Fin-de-Siècle Socialism and Other Essays (New York: Routledge, 1988); Force Fields: Between Intellectual History and Cultural Critique (New York: Routledge, 1993); Downcast Eves: The Denigration of Vision in Twentieth-Century French Thought (Berkeley: University of California Press, 1994); Cultural Semantics: Keywords of Our Time (Amherst: University of Massachusetts Press, 1998); Refractions of Violence (New York: Routledge, 2003); The Virtues of Mendacity: On Lying in Politics (Charlotte: Univerity of Virginia Press, 2009). Articles by Jay relevant in respect to the topics of the interview include: "Historical Explanation and the Event: Reflections on the Limits of Contextualization", New Literary History 42 (2011): 557-571, and "Intentionality and Irony: The Missed Encounter of Quentin Skinner and Hayden White", History and Theory. 52 (2013): 32-48.

Gonzalo Bustamante is professor of political philosophy at the University of Adolfo Ibáñez. E-mail: gonzalo.bustamante@uai.cl; https:/ / uai.academia.edu/GonzaloBustamante. 